\title{
VENTILATION AND BLOOD GASES \\ IN ANAESTHETIZED PATIENTS ${ }^{\circ}$
}

\author{
Martin I. Gold, M.D., AND Martin HelRich, M.D. $\dagger$
}

RECENTLY the safety of intermittent positive pressure breathing (IPPB) from the standpoint of oxygenation has been questioned. An increase in physiologic dead space ( Vo (phys)) and ventilation-perfusion inequality have been demonstrated during IPPB in both awake and anaesthetized subjects. ${ }^{1-11}$ An anatomical shunt with venous admixture may result from ventilation with constant volumes. The degree of this disturbance, the time relationships between onset and maximum hypoxaemia, and its clinical significance remain to be evaluated.

The purpose of this study was to evaluate the significance of blood gas changes during anaesthesia and IPPB. Although evidence is available to the contrary, we wanted to test the validity of the assumption that during the awake, spontaneously breathing state and the anaesthetized IPPB state similar inhaled oxygen tensions $\left(\mathrm{PI}_{\mathrm{O}_{2}}\right)$, tidal volumes $(\mathrm{VT})$, and respiratory rates $(\mathrm{f})$ should provide similar blood gas values in the same patient. Results proved that the assumption was not valid, although in many instances higher arterial oxygen tensions occurred at tidal volumes considerably less than are used during the management of clinical anaesthesia.

\section{Experimental METHoD}

Surgical patients were placed on the operating table one hour after the intramuscular injection of $100 \mathrm{mg}$. pentobarbital and $0.5 \mathrm{mg}$. atropine. A Cournand needle was placed in the brachial artery and an intravenous infusion of 5 per cent dextrose and water initiated. A mouthpiece was inserted and a nose clip applied. After a tight seal was ensured, a recently calibrated Wright respirometer was attached to measure expiratory $V_{T}$ and minute volume $\left(\dot{V}_{E}\right)$. Two arterial samples were withdrawn in the conscious state, the first while the patient was breathing air. A non-rebreathing valve and reservoir bag with 100 per cent oxygen were then attached. This was followed by 5 minutes of denitrogenation and, in turn, succeeded by 5 minutes of inhalation of 50 per cent oxygen in nitrogen through the same breathing system. The second arterial sample (the awake control) was then withdrawn while $\dot{V}_{E}$ and $f$ were again measured.

Thiopental was then injected intravenously followed by succinylcholine. The trachea was then intubated. Fifty per cent $\mathrm{O}_{2}$ in $\mathrm{N}_{2} \mathrm{O}$-halothane was inhaled and the patients' respirations were controlled with the same pressure-regulated ventilator during all subsequent measurements. This $\mathrm{O}_{2}$ concentration was maintained and monitored at a point distal to the inspiratory valve in a circle $\mathrm{CO}_{2}$ absorption

\footnotetext{
'This investigation was supported by Public Health Service Research Grant HE-06429 from the National Institutes of Health.

†Department of Anesthesiology, University of Maryland School of Medicine and Hospital, Baltimore, Maryland.
} 
system by means of a Beckman D-2 paramagnetic analyser. The patient was given periodic injections of d-tubocurarine to ensure apnoea while on the ventilator with the same VT and $f$ as his awake control. In a few patients either VT or $f$ was varied, after which arterial samples were withdrawn and volume measurements made.

Blood samples were withdrawn at 15-minute intervals after the ventilator was set to inflate the lungs at the control values. Surgery lasted from 30 minutes to five hours in the 13 patients studied. The arterial blood was placed in heparinized syringes and iced for analysis of arterial oxygen tension $\left(\mathrm{Pa}_{\mathrm{O}_{2}}\right)$ by means of an Astrup radiometer unit and an oxygen electrode calibrated with gases. The $\mathrm{pH}$ meter and equilibration technique were used to analyse arterial carbon dioxide tension $\left(\mathrm{PaCO}_{2}\right)$. Calibration gases were analysed by the Scholander method; all arterial samples were analysed three times.

\section{RESULTS}

In Table I the physiologic information regarding the 13 patients is shown. Tables II, III, and IV display the individual $\mathrm{Pa}_{\mathrm{O}_{2}}, \mathrm{~Pa}_{\mathrm{CO}_{2}}$ and $\dot{\mathrm{V}}_{\mathrm{E}}$ data of each patient breathing air and 50 per cent $\mathrm{O}_{2}$ in $\mathrm{N}_{2}$ awake and, subsequently, anaesthetized. Samples were withdrawn each 15 minutes after IPPB was initiated. $\mathrm{Pa}_{\mathrm{CO}_{2}}$ was determined each 30 minutes. Those 22 samples withdrawn at $\mathrm{VT}$ and/or $f$ not identical to the awake control are indicated by an asterisk $\left({ }^{\circ}\right)$.

Figure 1 displays the mean \pm 1 S.D. of the $\mathrm{Pa}_{\mathrm{O}_{2}}, \mathrm{~Pa}_{\mathrm{CO}_{2}}$ and $\dot{\mathrm{V}}_{\mathrm{E}}$ (including $\mathrm{VT}$, $f$, and estimated $\dot{V}_{A}$ ) for the 13 patients during the three conditions: (a) awake, spontaneously breathing air; $(b)$ awake, spontaneously breathing 50 per cent $\mathrm{O}_{2}$ in $\mathrm{N}_{2}$ for five minutes after denitrogenation; and $(c)$ anaesthetized with 50 per cent $\mathrm{O}_{2}$ in $\mathrm{N}_{2} \mathrm{O}$-halothane during IPPB at $\mathrm{VT}$ and $\mathrm{f}$ almost identical to those during situation $(b)$.

TABLE I

Cinical Information

\begin{tabular}{|c|c|c|c|c|c|c|c|}
\hline Patient & Sex & Age & Ht. (in.) & Wt. (lbs.) & Surgery & $\begin{array}{c}\text { Thiopental } \\
\text { (mg.) }\end{array}$ & $\begin{array}{c}\text { d-Tubocurarine } \\
\text { (mg.) }\end{array}$ \\
\hline 1. J.G. & $\mathrm{M}$ & 43 & 71 & 150 & resection & 200 & Succinylcholine \\
\hline $\begin{array}{l}\text { 2. M.L. } \\
\text { 3. E.T. } \\
\text { 4. B.A. } \\
\text { 5. A.S. }\end{array}$ & $\begin{array}{l}\mathrm{F} \\
\mathrm{M} \\
\mathrm{F} \\
\mathrm{F}\end{array}$ & $\begin{array}{l}76 \\
45 \\
42 \\
63\end{array}$ & $\begin{array}{l}62 \\
68 \\
63 \\
62\end{array}$ & $\begin{array}{l}100 \\
150 \\
125 \\
140\end{array}$ & $\begin{array}{l}\text { cholecystectomy } \\
\text { gastrectomy } \\
\text { expl. lap. } \\
\text { lysis of }\end{array}$ & $\begin{array}{l}250 \\
200\end{array}$ & $\begin{array}{l}24 \\
57 \\
24\end{array}$ \\
\hline 6. J.H. & M & 66 & 68 & 130 & $\begin{array}{l}\text { abd. adhesions } \\
\text { Appendectomy \& } \\
\text { colostomy }\end{array}$ & $\begin{array}{l}150 \\
150\end{array}$ & 21 \\
\hline $\begin{array}{l}\text { 7. L.D. } \\
\text { 8. G.W. } \\
\text { 9. A.K. }\end{array}$ & $\begin{array}{l}\mathrm{M} \\
\mathrm{F} \\
\mathrm{M}\end{array}$ & $\begin{array}{l}47 \\
48 \\
78\end{array}$ & $\begin{array}{l}66 \\
62 \\
69\end{array}$ & $\begin{array}{l}187 \\
110 \\
160\end{array}$ & $\begin{array}{l}\text { ing. her niorrhaphy } \\
\text { hysterectomy } \\
\text { perineal }\end{array}$ & $\begin{array}{l}100 \\
225 \\
275\end{array}$ & $\begin{array}{l}27 \\
27 \\
21\end{array}$ \\
\hline 10. A.G. & M & 55 & 70 & 188 & $\begin{array}{l}\text { prostatectomy } \\
\text { radical neck } \\
\text { dissection }\end{array}$ & $\begin{array}{l}200 \\
100\end{array}$ & $\begin{array}{l}21 \\
48\end{array}$ \\
\hline $\begin{array}{l}\text { 11. E.W. } \\
\text { 12. E.B. } \\
\text { 13. M.S. }\end{array}$ & $\begin{array}{l}F \\
F \\
F\end{array}$ & $\begin{array}{l}65 \\
51 \\
37\end{array}$ & $\begin{array}{l}66 \\
64 \\
64\end{array}$ & $\begin{array}{l}176 \\
125 \\
140\end{array}$ & $\begin{array}{l}\text { sympathectomy } \\
\text { cholecystectomy } \\
\text { vein ligation } \\
\text { and stripping }\end{array}$ & $\begin{array}{l}225 \\
175 \\
175\end{array}$ & $\begin{array}{l}42 \\
38 \\
15\end{array}$ \\
\hline
\end{tabular}




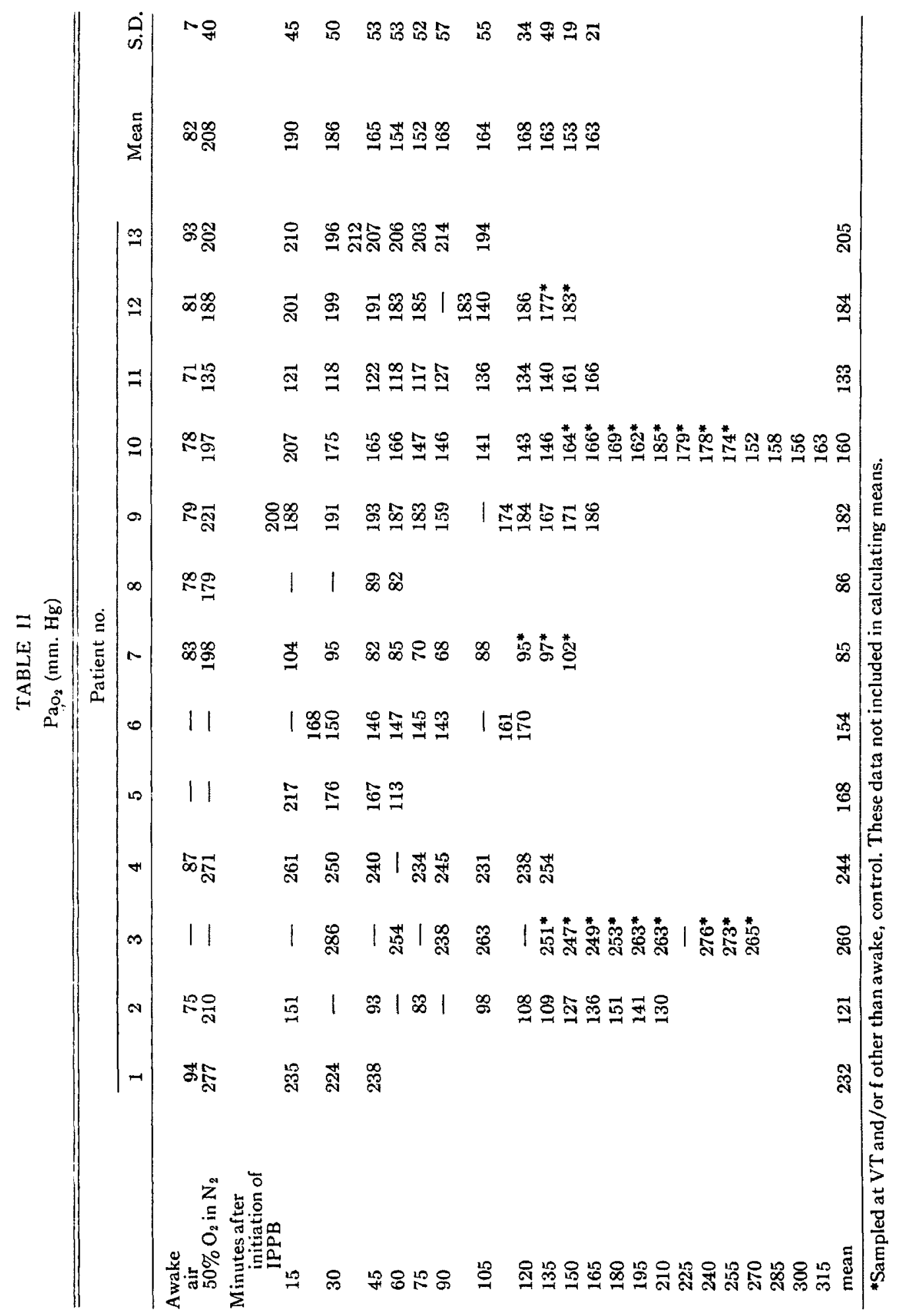




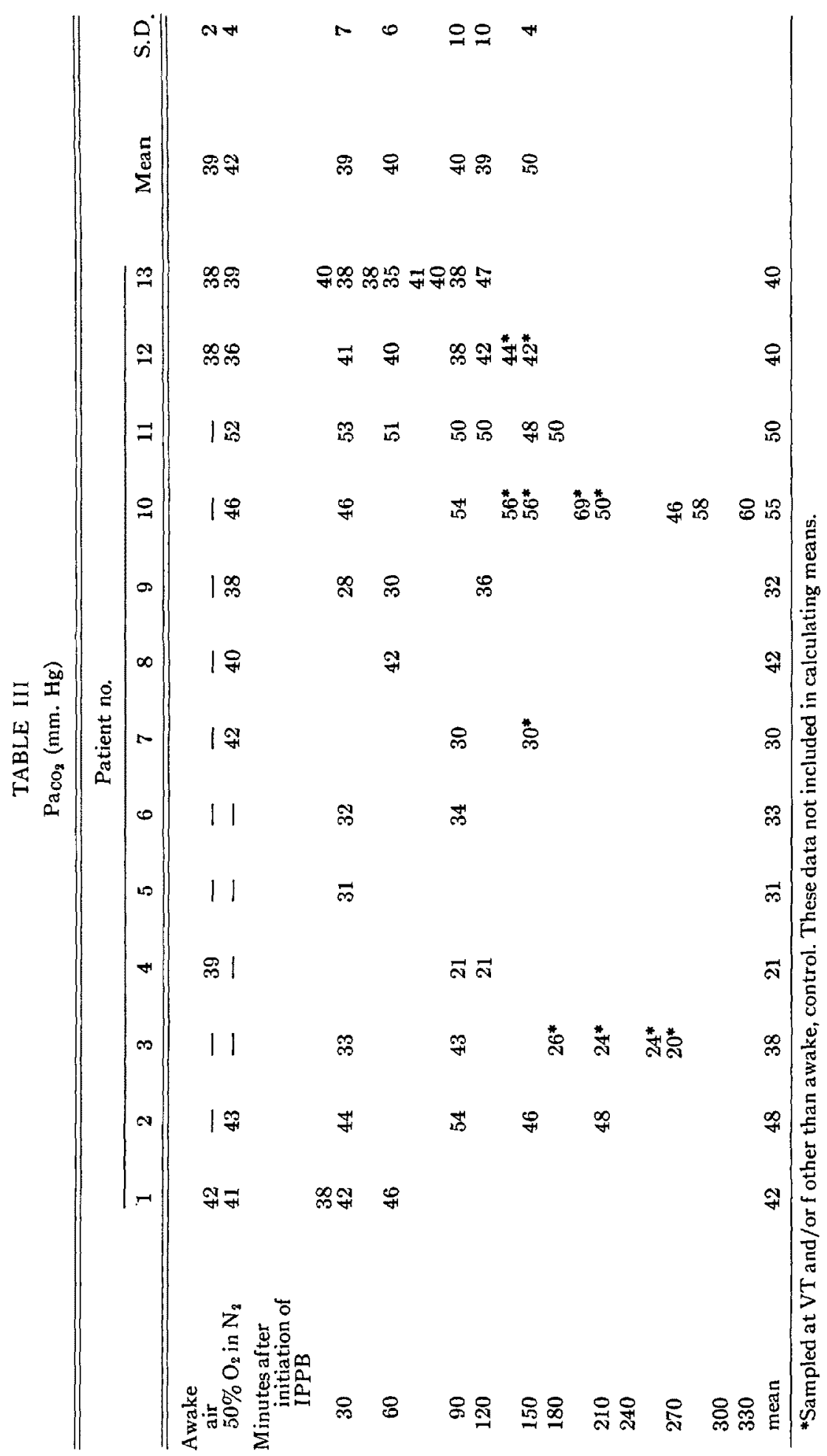




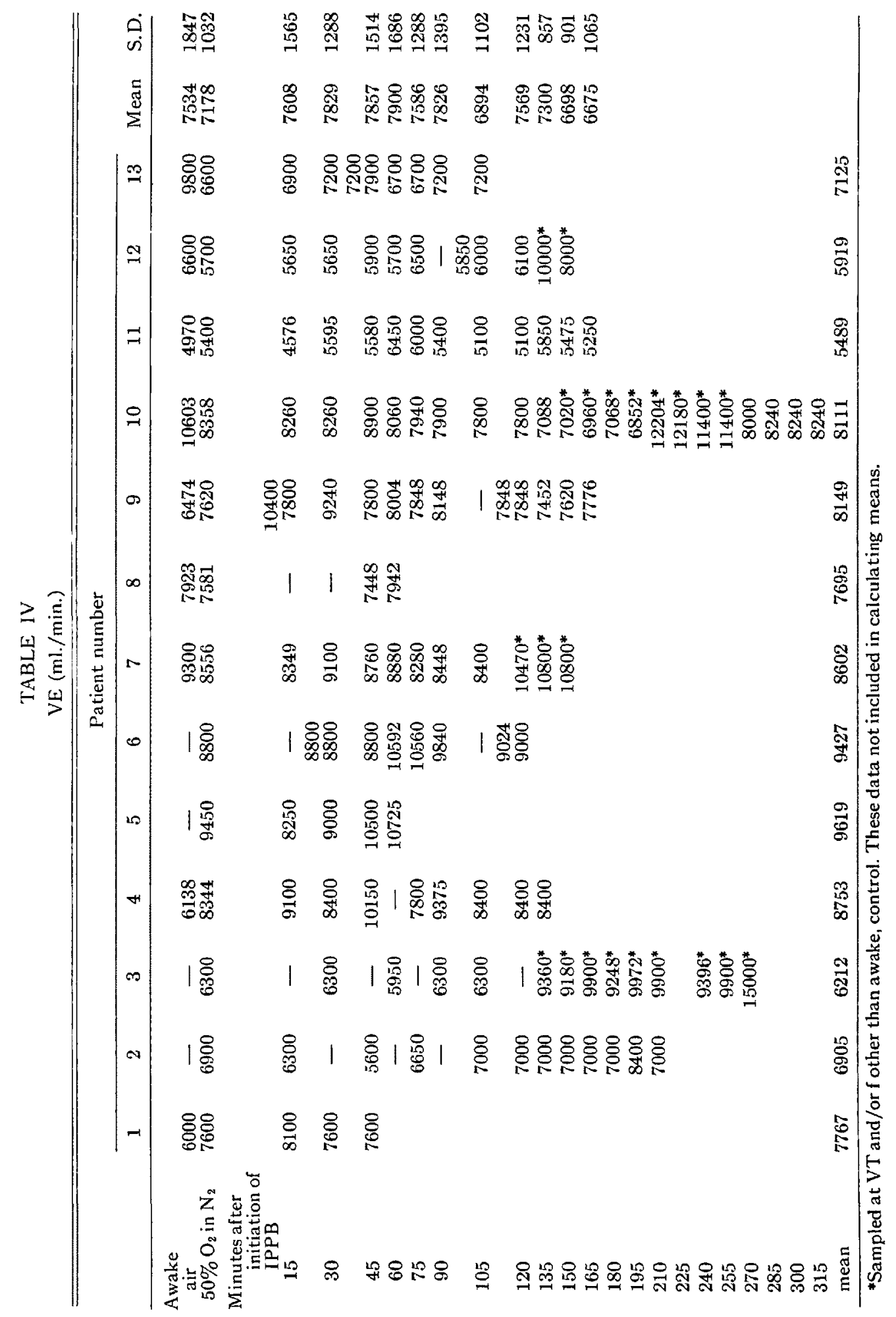




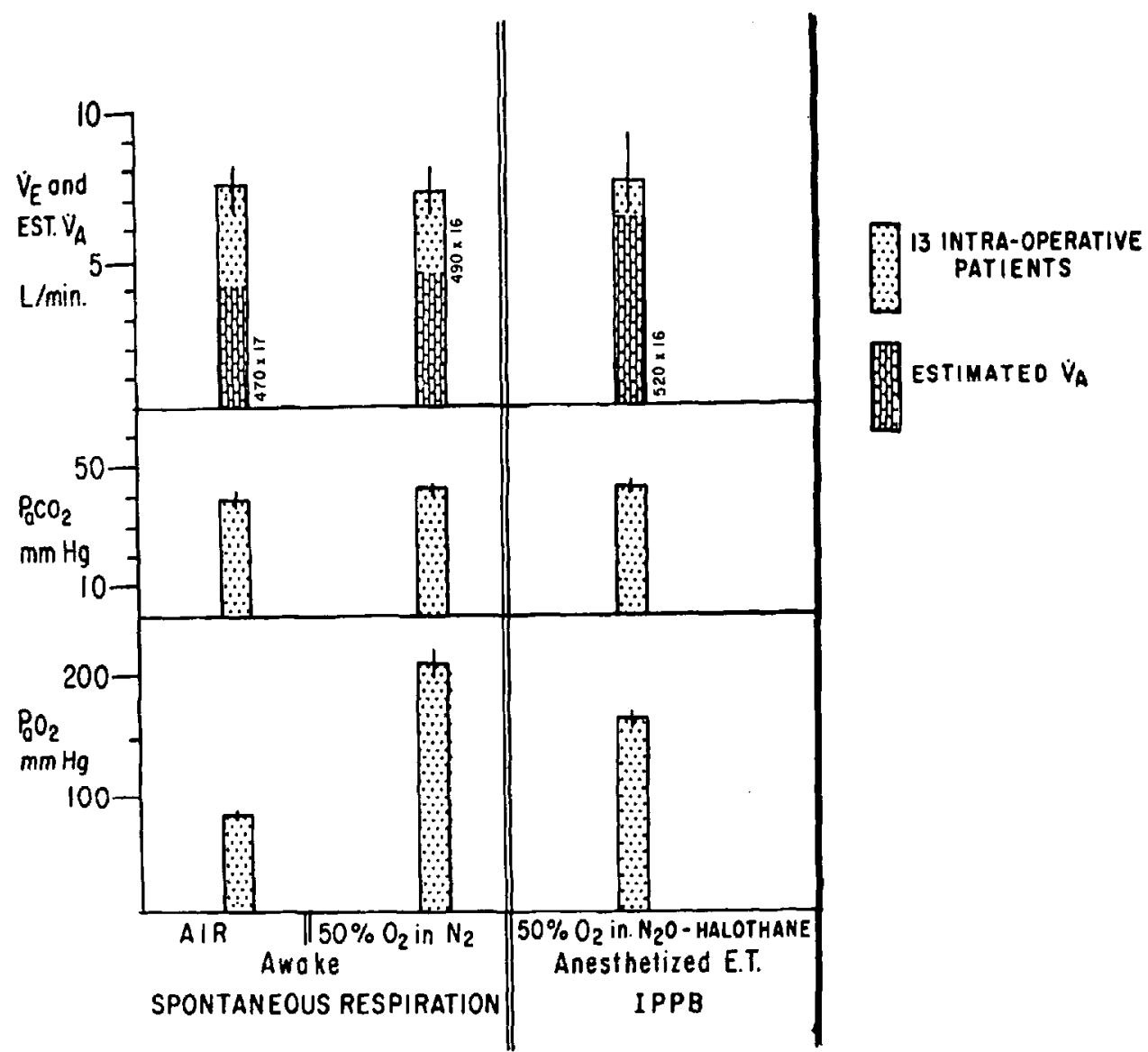

Figune 1. Volumes and gas tensions during spontaneous and intermittent positive pressure breathing.

$\overline{\mathrm{Pa}}_{\mathrm{O}_{2}}$ with air was $82 \mathrm{~mm}$. $\mathrm{Hg}, 208 \mathrm{~mm}$. during 50 per cent $\mathrm{O}_{2}$ and $167 \mathrm{~mm}$. during IPPB and anaesthesia (mean value from 99 blood samples). This represents a drop of $41 \mathrm{~mm} . \mathrm{Hg}(p<.05) . \overline{\mathrm{Pa}}_{\mathrm{CO}_{2}}$ during conditions $(a),(b)$, and $(c)$ was 39,42 , and $42 \mathrm{~mm}$. $\mathrm{Hg}$ respectively. $\grave{\mathrm{V}}_{\mathrm{E}}$ was $7.53,7.18$ and $7.59 \mathrm{~L} . / \mathrm{min}$. during conditions $(a),(b)$, and $(c)$. There was, therefore, a significant drop in $\overline{\mathrm{Pa}}_{\mathrm{O}_{2}}$ despite almost identical $\overline{\mathrm{V}}_{\mathrm{E}}, \overline{\mathrm{V}} \mathrm{T}, \overline{\mathrm{f}}, \overline{\mathrm{P}}_{\mathrm{I}_{2}}$ and $\overline{\mathrm{P}}_{\mathrm{C}_{\mathrm{CO}_{2}}}$.

Figure 2 plots the average $\mathrm{Pa}_{\mathrm{O}_{2}}$ and $\dot{\mathrm{V}}_{\mathrm{E}}$ at 15 -minute intervals and $\mathrm{Pa}_{\mathrm{CO}_{2}}$ at 30-minute intervals in the 13 patients (see Table II). The data were plotted up to 165 minutes of IPPB. Not all patients had measurements during each 15minute interval. While $\dot{\mathrm{V}}_{\mathrm{E}}$ and $\mathrm{Pa}_{\mathrm{CO}_{2}}$ remained at levels close to the awake control, the $\mathrm{Pa}_{\mathrm{O}_{2}}$ gradually fell, reaching its lowest levels at 60 and 75 minutes.

\section{Discussion}

It is accepted that hypoxaemia may occur during anaesthesia and IPPB and that: (a) VD (phys) increases and (b) a physiologic shunt occurs. ${ }^{1-11}$ Further, pulmonary mechanics during IPPB are different from those during spontaneous 


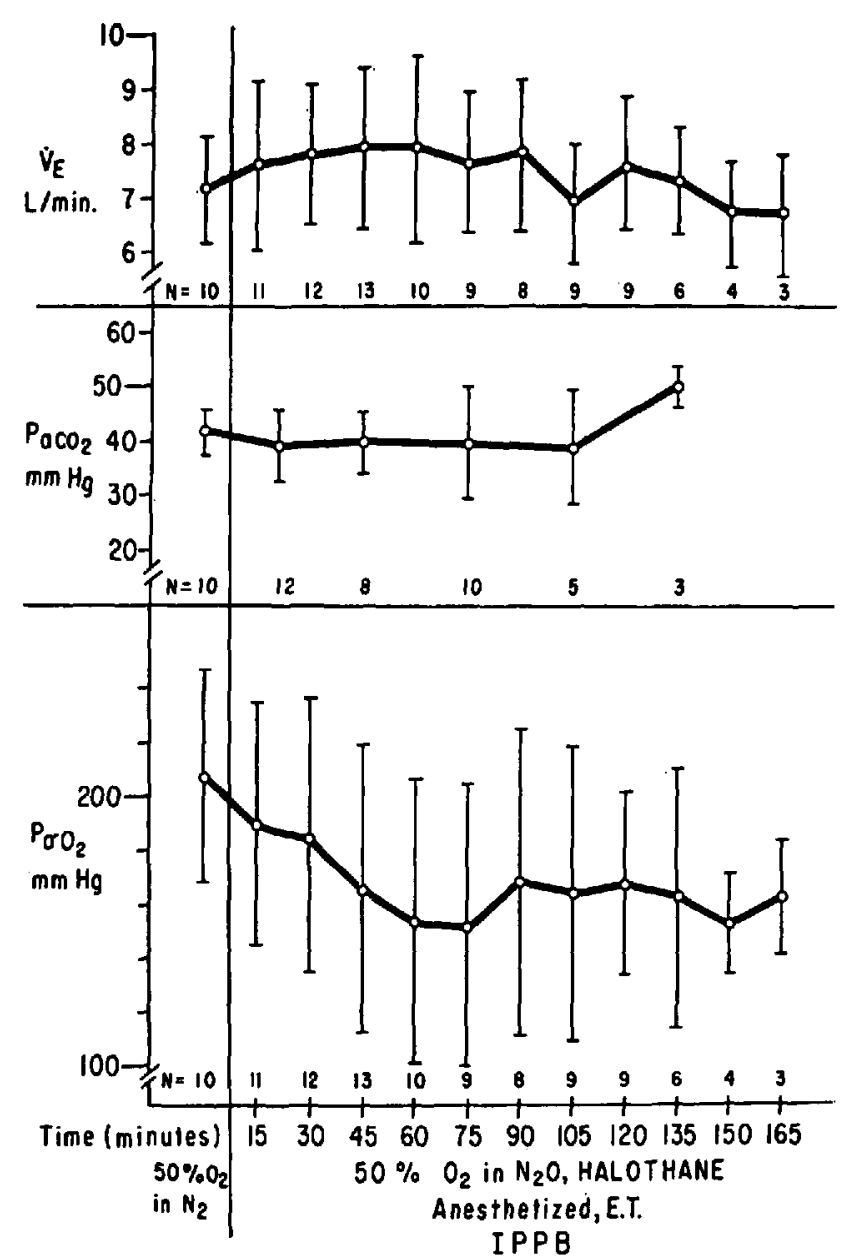

FIGURE 2. Variation in blood gases with time during intermittent positive pressure breathing.

breathing. ${ }^{12}$ A decrease in pulmonary compliance $\left(C_{L}\right)$ in both awake and anaesthetized states occurs. ${ }^{5,8,13,14}$ The magnitude and incidence of these abnormalities and therefore their significances are not known. It is well to realize that during anaesthesia and spontaneous breathing, an increase in venous admixture and a decrease in $\mathrm{CL}_{\mathrm{L}}$ also occur. ${ }^{14,15}$

In this study, the reduction of $\overline{\mathrm{P}}_{\mathrm{O}_{2}}$ from 208 to $167 \mathrm{~mm} . \mathrm{Hg}(p<.05)$ in the passage from the awake to the anaesthetized state during IPPB, despite similar $\mathrm{PI}_{\mathrm{O}_{2}}, V_{\mathrm{T}}$, and $\mathrm{f}$, indicates the existence of some abnormality. This cannot be explained on the basis of decreased effective $\dot{\mathrm{V}}_{\mathrm{A}}$ since $\overline{\mathrm{P}} \mathrm{a}_{\mathrm{CO}_{2}}$ did not change from the awake to the anaesthetized state during IPPB.

In addition to the lowered $\mathrm{Pa}_{\mathrm{O}_{2}}$ under these conditions, there was a wide variation in individual $\mathrm{Pa}_{\mathrm{O}_{2}}$ and $\mathrm{Pa}_{\mathrm{CO}_{2}}$ response. Of the 13 normals, three patients $\left(\# 2,7\right.$, and 8) had $\mathrm{Pa}_{\mathrm{O}_{2}}$ values below $100 \mathrm{~mm}$. $\mathrm{Hg}$ at some time during anaesthesia, and of these only patient \#2 had concomitant hypercarbia. None of the low $\mathrm{Pa}_{\mathrm{O}_{2}}$ values was significantly lower than the awake control $\mathrm{Pa}_{\mathrm{O}_{2}}$ on room air. 
Since $\mathrm{N}_{2}$ is less soluble than $\mathrm{N}_{2} \mathrm{O}$ and might effectively prevent absorption atelectasis, it might be believed that the difference in background gases $\left(\mathrm{N}_{2}\right.$ vs. $\left.\mathrm{N}_{2} \mathrm{O}\right)$ from the awake control to the anaesthetized state could have contributed to the lower $\mathrm{Pa}_{\mathrm{O}_{2}}$ during anaesthesia and IPPB. In a preliminary report, Webb and Nunn ${ }^{16}$ studied venous admixture in two groups of patients, one inhaling $\mathrm{N}_{2}$ and the other $\mathrm{N}_{2} \mathrm{O}$; both groups breathed both spontaneously and mechanically but did not develop hypercarbia. $A$ greater per cent admixture with $\mathrm{N}_{2}$ than $\mathrm{N}_{2} \mathrm{O}$ was found, and we must therefore presume that $\mathrm{N}_{2} \mathrm{O}$ did not contribute to a lower $\mathrm{Pa}_{\mathrm{O}_{2}}$ during IPPB in this study.

Despite the variety of $\mathrm{Pa}_{\mathrm{O}_{2}}$ responses, the remaining ten patients who did not develop any degree of hypoxaemia maintained $\mathrm{Pa}_{\mathrm{O}_{2}}$ values between 150 and 250 $\mathrm{mm}$. Hg. These patients were ventilated at a $\mathrm{VT}_{\mathbf{T}}$ and $\mathrm{f}$ almost identical to their awake control values with 50 per cent $\mathrm{O}_{2}$ inhalation. Patients \#1, 7, 9, 11, and 13 had, on occasion, a "low" VT or $\mathrm{f}$. Patient 5 was an exception since his $\mathrm{Pa}_{2}$ began to fall but never reached hypoxic levels. The surgery lasted one hour and further data are lacking.

The $\mathrm{Pa}_{\mathrm{CO}_{2}}$ information yielded a variety of patient responses. In general, values were equal to or lower than their respective awake controls. Patient \#10 had an elevated $\mathrm{Pa}_{\mathrm{CO}_{2}}$ in the presence of a $\mathrm{Pa}_{2}$ at the $150 \mathrm{~mm}$. $\mathrm{Hg}$ level. When the VT was increased to $1000 \mathrm{ml}$. ( $2 \frac{1}{2}$ times control), and the f dropped from 20 to 12 , the $\mathrm{Pa}_{\mathrm{CO}_{2}}$ also dropped. The $\mathrm{Pa}_{\mathrm{O}_{2}}$ changed little in either case. Patient \#11 also had slightly elevated $\mathrm{Pa}_{\mathrm{CO}_{2}}$, but his control value was $52 \mathrm{~mm}$. $\mathrm{Hg}$.

The magnitude of the alveolar-arterial carbon dioxide gradient $\left(\mathrm{A}-\mathrm{aDCO}_{2}\right)$ is considerably smaller than the alveolar-arterial oxygen gradient $\left(\mathrm{A}-\mathrm{aDo}{ }_{2}\right)^{17}$ partly because of the more linear dissociation curve at the normal physiological level and partly because of the smaller difference between the mixed venous and arterial carbon dioxide tensions. With respect to large shunts, one might therefore predict a smaller change in the $\mathrm{A}-\mathrm{aDcO}$ than $\mathrm{A}-\mathrm{aDo}_{2}$. For example, with a normal venous to arterial $\mathrm{PCO}_{2}$ difference of $5 \mathrm{~mm}$. $\mathrm{Hg}$, a 10 per cent shunt will yield only a $0.5 \mathrm{~mm}$. $\mathrm{Hg} \mathrm{A-aDco} 2$ but an $\mathrm{A}-\mathrm{aDo}_{2}$ of approximately $150 \mathrm{~mm} . \mathrm{Hg}$ when 50 per cent $\mathrm{O}_{2}$ is inhaled. ${ }^{18}$ The approximately $40 \mathrm{~mm}$. $\mathrm{Hg}$ drop in $\mathrm{Pa}_{\mathrm{O}_{2}}$ from 50 per cent $\mathrm{O}_{2}$ in $\mathrm{N}_{2}$ to 50 per cent $\mathrm{O}_{2}$ in $\mathrm{N}_{2} \mathrm{O}$-halothane is equivalent to an increase in shunt of about 3 per cent (Fig. 1).

Figure 2 is a chronologic plot of the mean data at 15-minute intervals. At 60 and 75 minutes after the initiation of IPPB, during anaesthesia at a VT and $f$ determined by the patient when awake, the lowest $\mathrm{Pa}_{\mathrm{O}_{2}}$ values occurred. After 75 minutes no further decrease developed and an upward trend was noted. Others have noted a similar progressive decline in $\mathrm{Pa}_{\mathrm{O}_{2}}$ during IPPB. ${ }^{5,6} \mathrm{We}$ may conjecture that homeostatic mechanisms, perhaps reflex in nature during such constant volume ventilation, become manifest at approximately one hour and cause a reversal of the probable physiologic shunt. ${ }^{19}$

\section{Summary and Conclusions}

Blood gases, tidal volumes, and respiratory rates were measured preoperatively and during surgery with intermittent positive pressure breathing of 50 per cent 
oxygen. The ventilator was set to provide a tidal volume and rate closely approximating that in the awake state.

$\overline{\mathrm{Pa}}_{\mathrm{O}_{2}}$ dropped significantly during IPPB despite the similar $\mathrm{PI}_{\mathrm{O}_{2}}, \mathrm{VT}, \mathrm{f}$, and $\dot{\mathrm{V}} \mathbf{E}$. $\overline{\mathrm{P}} \mathrm{P}_{\mathrm{CO}_{2}}$ remained the same. As time elapsed, a progressive fall in $\overline{\mathrm{P}} \mathrm{a}_{2}$ occurred. The $\mathrm{Pa}_{\mathrm{O}_{2}}$ reached its minimum at approximately one hour after the initiation of IPPB. Individual patient responses varied considerably for both changes in $\mathrm{Pa}_{2}$ and $\mathrm{Pa}_{\mathrm{CO}_{2}}$. Although three patients developed $\mathrm{Pa}_{\mathrm{O}_{2}}$ values below 100 $\mathrm{mm}$. $\mathrm{Hg}$, none was considered hypoxaemic since the respective $\mathrm{Pa}_{\mathrm{O}_{2}}$ was at a level above the air control. Some $\mathrm{Pa}_{\mathrm{O}_{2}}$ values dropped approximately $150 \mathrm{~mm}$. $\mathrm{Hg}$ below the awake control while others remained at the $250 \mathrm{~mm}$. $\mathrm{Hg}$ level. It should be realized that the tidal volumes used were lower than that during the usual clinical administration of anaesthesia. Changes in $\mathrm{Pa}_{\mathrm{CO}_{2}}$ were not usually related to changes in $\mathrm{Pa}_{\mathrm{O}_{2}}$, and hypocarbia and acceptable estimated $\dot{\mathrm{V}}_{\mathrm{A}}$ were frequently associated with a $\mathrm{Pa}_{\mathrm{O}_{2}}$ lower than during the control. Therefore, under the same conditions, it is concluded that if the tidal volume and respiratory rate used during IPPB are identical to those of the awake control, then during the inhalation of 50 per cent $\mathrm{O}_{2}$ patients are able to maintain normal $\mathrm{Pa}_{\mathrm{CO}_{2}}$ and slightly lower $\mathrm{Pa}_{\mathrm{O}_{2}}$.

\section{RÉSUMÉ}

Chez 13 malades, nous avons mesuré à toutes les 15 minutes avant et durant l'anesthésie et la chirurgie, alors que le malade respirait sous pression positive intermittente, nous avons mesuré les gaz du sang, les volumes courants et la vitesse de la respiration. Le ventilateur fournissait spécifiquement un air courant et une vitesse respiratoire indentiques à ceux du malade réveillé. Le taux d'oxygène inhalé était de 50 pour cent.

$\mathrm{La} \mathrm{Pa}_{\mathrm{O}_{2}}$ a baissé de façon marquée durant la pression positive intermittente; la $\mathrm{Pa}_{\mathrm{CO}_{2}}$ est demeurée la même. Le changement de la $\mathrm{Pa}_{\mathrm{O}_{2}}$ a été progressif et a atteint son sommet au bout d'une heure. Bien que, chez certains malades, la $\mathrm{Pa}_{\mathrm{O}_{2}}$ ait été au-dessous de $100 \mathrm{~mm}$. $\mathrm{Hg}$, nous n'avons pas estimé qu'il existait d'hypoxémie puisque la $\mathrm{Pa}_{\mathrm{O}_{2}}$ est demeurée au-dessus du contrôle lorsque le malade respirait de l'air. Nous avons observé des variations individuelles considérables de la $\mathrm{Pa}_{\mathrm{O}_{2}}$ et de la $\mathrm{Pa}_{\mathrm{CO}_{2}}$. Les changements de la $\mathrm{Pa}_{\mathrm{CO}_{2}}$ n'étaient pas habituellement à l'opposé de ceux de la $\mathrm{Pa}_{\mathrm{O}_{2}}$ et l'hypocarbie en présence d'un volume/minute adéquat s'accompagnait généralement d'une $\mathrm{Pa}_{\mathrm{O}_{2}}$ plus basse que durant le contrôle.

\section{ACKNOWLEDGMENTS}

The authors acknowledge the enthusiastic help of Mr. F. E. Knowles III, Miss Barbara Eerligh, and Mrs. Lillian Chambliss.

\section{Abbreviations}

$\begin{array}{ll}V_{T} & \text { tidal volume } \\ \dot{V}_{\mathbf{E}} & \text { minute volume }\end{array}$




$\begin{array}{ll}\mathbf{f} & \text { respiratory rate/minute } \\ \dot{\mathrm{V}}_{\mathrm{A}} & \text { alveolar ventilation } \\ \mathrm{Pa}_{\mathrm{O}_{2}} & \text { arterial oxygen tension } \\ \mathrm{Pa}_{\mathrm{CO}_{2}} & \text { arterial carbon dioxide tension } \\ \mathrm{A}-\mathrm{aDo} & \text { alveolar-arterial oxygen gradient } \\ \mathrm{A}-\mathrm{aDCO} & \text { alveolar-arterial carbon dioxide gradient } \\ \mathrm{VD} \text { (phys) } & \text { physiologic dead space } \\ \mathrm{Pt}_{\mathrm{O}_{2}} & \text { inhaled oxygen tension } \\ \dot{\mathrm{Q}} / \mathrm{Q} t \times 100=\text { Per cent physiologic shunt } \uparrow\end{array}$

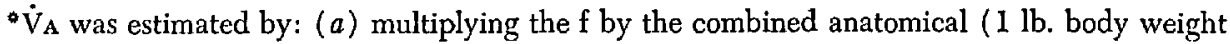
equals $1 \mathrm{ml}$.) and mechanical (mouthpiece, E. T. tube, connectors, Wright respirometer) dead spaces, and $(b)$ subtracting this figure from $\dot{V}_{E}$.

†This was estimated by using the simplified version of the alveolar gas equation for 50 per cent $\mathrm{O}_{2}$ :

$$
\mathrm{P}_{\mathrm{O}_{2}}=1 / 2(\mathrm{~PB}-47)-\mathrm{Pa}_{\mathrm{CO}_{2}} \text {. }
$$

Here $\mathrm{PA}_{\mathrm{O}_{2}}$ is alveolar oxygen tension, $\mathrm{PB}$ is barometric pressure, and 47 is water vapour pressure.

The per cent shunt was estimated from

$$
\dot{\mathrm{Q}}_{\mathrm{s}} / \dot{\mathrm{Q}} \mathrm{t}=\left(\mathrm{Cc}_{\mathrm{O}_{2}}-\mathrm{Ca}_{\mathrm{O}_{2}}\right) \div\left(\mathrm{Cc}_{\mathrm{O}_{2}}-\mathrm{Cv}_{\mathrm{O}_{2}}\right) \text {. }
$$

Here $\mathrm{Cc}_{\mathrm{O}_{2}}=\mathrm{O}_{2}$ content of blood leaving alveolar capillaries; $\mathrm{Ca}_{\mathrm{O}_{2}}=\mathrm{O}_{2}$ content of arterial blood; $\mathrm{C}_{\mathrm{O}_{2}}=\mathrm{O}_{2}$ content of mixed venous blood. Therefore,

$$
\dot{\mathrm{Q}}_{\mathrm{s}} / \dot{\mathrm{Q}} \mathrm{t}=\left(\mathrm{P}_{\mathrm{A}_{\mathrm{O}_{2}}}-\mathrm{Pa}_{\mathrm{O}_{2}}\right) 0.0031 \div\left(\mathrm{Cc}_{\mathrm{O}_{2}}-\mathrm{C}_{\mathrm{O}_{2}}\right) \text {. }
$$

It follows then, if we assume $\mathrm{Cc}_{\mathrm{O}_{2}}-\mathrm{Cv}_{\mathrm{O}_{2}}$ equals 4.5 volumes per cent, that with a $\mathrm{PA}_{\mathrm{O}_{2}}$ of $316 \mathrm{~mm} . \mathrm{Hg}$, and $\mathrm{Pa}_{\mathrm{O}_{2}}$ of $200 \mathrm{~mm}$. $\mathrm{Hg}$,

$$
\dot{\mathrm{Q}} \mathrm{s} / \dot{\mathrm{Q}} \mathrm{t}=(316-200) 0.0031 / 4.5=7.5 \% \text { shunt. }
$$

\section{REFERENCES}

1. Campeelu, E. J. M.; Nunn, J. F.; \& Pecketr, B. W. A Comparison of Artificial Ventilation and Spontaneous Respiration with Particular Reference to Ventilation-Bloodflow Relationships. Brit. J. Anaesth. 30: 166 (1958).

2. NunN, J. F. \& Hile, D. W. Respiratory Dead Space and Arterial to End-Tidal CO., Tension Difference in Anesthetized Man. J. Appl. Physiol. 15: 383 (1960).

3. Frumin, M. K. et al. Alveolar-Arterial $\mathrm{O}_{2}$ Difference during Artificial Respiration in Man. J. Appl. Physiol. 14: 694 (1959).

4. Stark, D. C. C. \& Smrth, H. Pulmonary Vascular Changes during Anaesthesia. Brit. J. Anaesth. 32: 460 (1960).

5. Bendixen, H. H. et al. Impaired Oxygenation in Surgical Patients during General Anesthesia with Controlled Ventilation: A Concept of Atelectasis. New England J. Med. 269: 991 (1963).

6. Conway, E. M. \& Payne, J. P. Hypoxaemia Associated With Anaesthesia and Controlled Respiration. Lancet 1: 12 (1964).

7. Hedley-Whyte, J.; Laver, M. B.; \& Bendixen, H. H. Effect of Changes in Tidal Ventilation on Physiologic Shunting. Am. J. Physiol. 206: 891 (1964).

8. Laver, M. B. et al. Lung Volume, Compliance, and Arterial Oxygen Tensions during Controlled Ventilation. J. Appl. Physiol. 19: 725 (1964).

9. Sykes, M. K.; Young, W. E.; \& Robinson, B. E. Oxygenation during Anaesthesia with Controlled Ventilation. Brit. J. Anaesth. 37: 314 (1965).

10. Nunn, J. F.; Bergman, N. A.; \& Coleman, A. J. Factors Influencing the Arterial Oxygen Tension during Anaesthesia with Artificial Ventilation. Brit. J. Anaesth. 37: 898 (1965).

11. Pontoppidan, H. et al. Ventilation and Oxygen Requirements during Prolonged ArtificiaI Ventilation in Patients with Respiratory Failure. New England J. Med. 273: 401 (1965). 
12. Gold, M. I.; Han, Y. A.; \& Helrich, M. Pulmonary Mechanics during Anesthesia: III. Influence of Intermittent Positive Pressure and Relation to Blood Gases. Anesth. \& Analg. 45: 631 (1966).

13. WAtson, W. E. Observations on the Dynamic Lung Compliance of Patients with Respiratory Weakness Receiving Intermittent Positive Pressure Respiration. Brit. J. Anaesth. 34: 690 (1962).

14. Gold, M. I. \& Helrich, M. Pulmonary Compliance during Anesthesia. Anesthesiology. 26: $281(1965)$.

15. NunN, J. F. Factors Influencing the Arterial Oxygen Tension during Halothane Anaesthesia with Spontaneous Respiration. Brit. J. Anaesth. 36: 327 (1964).

16. Webe, S. J. S. \& NunN, J. F. Comparison between Nitrogen and Nitrous Oxide in the Development of Venous Admixture during Anaesthesia. Anaesthesia. 21: 95 (1966).

17. RaHN, H. \& FArHI, L. E. Ventilation, Perfusion, and Gas Exchange: The VA/Q Concept, in W. O. Fenn and H. Rahn, Handbook of Physiology, Section 3: Respiration I. Baltimore: Williams and Wilkins (1964), chap. 3, pp. 751-54.

18. Nunn, J. F. The Lung as a Black Box. Canad. Anaesth. Soc. J. 13: 81 (1966).

19. Bonic, J. J. et al. Effects of Surgical Pneumothorax ọn Pulmonary Ventilation. Anesthesiology. 22: 955 (1961). 